216

Received: Fevruary 28, 2016

Accepted: March 31, 2016
Macedonian Journal of Animal Science, Vol. 6, No. 1, pp 59-64 (2016)

In print: ISSN $1857-6907$

On line: ISSN $1857-7709$

UDC: $637.5^{\prime} 62.053$

Original scientific paper

\title{
IMPROVEMENT OF THE METHODS OF CALCULATION OF RHEOLOGICAL CHARACTERISTICS OF RESILIENT-ELASTIC ENVIRONMENTS BY THE PENETRATION METHOD
}

\author{
Oksana Savinok \\ Odessa National Academy of Food Technologies, Odessa, Ukraine \\ savoksamit@mail.ru
}

\begin{abstract}
In this work the methods of calculation of limiting pressure of the displacement for resilient-elastic environments for the whole muscle beef for the use of different constants of cones are founded. Measurements of the size of penetration are carried out with the dynamic penetrometer in different periods of autolysis. The calculation of rheological characteristics was made with use before the established constants of conic indentors' cones with corners at top $30^{\circ}, 20^{\circ}, 10^{\circ}$. Factors which provide the minimum disorder of values LPS that allows to recommend them for the further calculations are chosen.
\end{abstract}

Key words: correctional of efficiency factor; whole muscle fabric; beef; dynamic penetrometer; limiting pressure of shift

\section{ПОДОБРУВАЊЕ НА МЕТОДИТЕ ЗА ПРЕСМЕТКА НА РЕОЛОШКИ КАРАКТЕРИСТИКИ НА ЕЛАСТИЧНА ПОВРШИНА НА МУСКУЛИТЕ СО МЕТОД НА ПЕНЕТРАЦИЈА}

\begin{abstract}
Во овој труд е претставен метод за пресметка на граничниот притисок на поместувањето во еластичната површина кај мускули на говедо со примена на различни конусни константи. Големината на пенетрација е мерена со динамичен пенетрометар во различни периоди на автолиза. Пресметката на реолошките својства е направена пред користење на конусни константи со агли од $30^{\circ}, 20^{\circ}$ и $10^{\circ}$. Избрани се фактори кои овозможуваат минимално отстапување на вредностите на LPS кои понатаму можат да се користат за пресметување.
\end{abstract}

Клучни зборови: фактор на ефикасност; мускул ткиво на цел мускул; говедско месо; пенетрометар

\section{INTRODUCTION}

Quality of meat raw materials is defined by organoleptic, physical, chemical and microbiological indicators. Many devices of control and corresponding techniques are developed for studying interesting properties of received raw materials or finished products. The greatest popularity on manufacture was received with those methods of research which provide the minimum duration of the analysis and yield the most exact result.

The express evaluation is provided with a visual control, however, for the complex charateristic the obtained data have a subjective character. By means of sense organs it is impossible to estimate objectively such indicators, as rigidity or tenderness of raw materials which have a great value at the stage of processing for manufacturers and after thermal processing for consumers.

Today for an appreciation assessment of rheological characteristics tool methods are used $[1,2]$. However each of them demands the specification at the calculation of parametres depending on pecularities of a structure, a chemical compound, conditions of measurement and other factors. One of the rheology axioms says that any real body [3], the food material has all rheological properties, but in each deformation process these properties appear to varying degrees, some of them important, some - irrelevant to the task. This is a common problem of the relation between the real object and settlement patterns in the exact sciences. The study of the rheological properties of a particular physical object allows you to expand the 
knowledge of its mechanical behavior under the influence of external forces. The need of studying the rheological properties of specific types of food raw materials and products due to the intensive development of technology, the advent of new machines, devices and technologies. The peculiarity of the development of modern equipment is complete automation of technological processes, so it is necessary to take into account all the details of changes in the properties of the processed material. In the industry there is no rheometeres, which would give absolutely invariant, independent of the parameters of instruments and measurement processes rheological parameters of the environment. Also, there is no method to determine the full set of indicators of the rheological properties of the material. Therefore rheometric study - these are links in the endless chain of studying the properties of real materials to give objective, complete and whatever properties.

At the research of resilient-elastic environments concerning whole muscle beef fabric it is rational to use the devices which principle of action consists of the introduction of working body in the research object. The dynamic penetrometer with a conic indentor as a portable device of the size of the penetration in the whole muscle raw materials has proved perfectly [4-6]. However, depending on the characteristics of the test object may be used with different cone apex angles. For plastic bodies, in particular minced meat, rational use of cones with angles of more than $30^{\circ}[5,6]$, for the elastic-elastic (whole muscle beef tissue) cones with apex angles less than $30^{\circ}$ [7].

Known researchers P. A. Rehbinder, N. N. Agranat, M. P. Volarovich, M. F. Shirokov, A. N. Abramov, V. A. Aret, V. D. Kosoy and others have studied the rheological properties of the model and real objects, and withdrew the corresponding equations and correction factors for the calculation of the basic rheological parameters. But not all of the proposed dependences can provide a minimal error in the calculation of the rheological properties of whole muscle beef at different stages of autolysis. Therefore, the aim of this work was to determine the coefficients for the calculation of the maximum shear stress of the selected objects, ensure the highest reliability of the results.

\section{MATERIAL AND METHODS}

For definition of the rheological properties by a penetrational method was used the rational fixed effort of the resistance of a product which depth of indentor introduction would make from 0.5 to 0.9 from the maximum value. In the experiments we have chosen the effort of resistance of a product which equal $0.5 \mathrm{~kg}$.

The measuring working body has been chosen the most widespread conic indentors with angles at top $30^{\circ}, 20^{\circ}, 10^{\circ}$. The carrying out of the experiment is with small-sized portable penetrometer marks PPM-4 [4, 6]. With the help of the given device we fixed the sizes of a penetration for chosen indentors at the achievement of the given effort of the resistance of a muscular fabric of meat.

The measurements of the rheological characteristics of whole muscle raw materials were spent on the hulks in a pair condition (1 hour after slaughter) and in the condition of posthumous rigor (in 44 hours) when it is possible to observe an essential difference in firm properties [7-9]. The experimental researches were spent in all directions of fibres. The calculation of the values of limiting pressure of the displacement was carried out using correctional coefficients [10]. The research objects were a group of hulks of cattle, carcasses grown up in one farm under identical conditions of fattening. Age of animals received for slaughter 14-16 months, the breed - Simmental. The control point was L. dorsi between 7-8 back vertebras.

\section{RESULTS AND DISCUSSION}

For the definition of rheological characteristics food raw material by researchers the constants of conic indentors [10] which are not universal for difficult food systems and to which the muscular fabric of beef concerns are received.

At the definition of dependence for calculation of the constant of Rebinder P. A cone is represented LPS, as the relation of the force of resistance of a product along a lateral surface of the cone $\left(P^{\prime}\right)$ to the area of this type $(F)$ wherein the tapered cone rheometer constant is calculated by:

$$
K^{\prime}=\cos ^{2} \alpha / \pi \operatorname{tg} \alpha=\cos ^{2} \alpha \cdot \operatorname{ctg} a / \pi .
$$

Rebinder's formulas [11-13], are convenient in that they are linear, and calculated parameter can be determined on the basis of experience. However, the use of this dependence (Formula 1) for calculating the cone constant and appropriate rheological characteristics in the study of elasticelastic bodies give greater accuracy. Other scientists have introduced correction factors to calculate the constants corresponding cones. 
For reduction of the constants received after various dependences, corresponding to reference conditions, A. N. Abramov has introduced to the correction factor equal 0.52 . The equation will assume the following air:

$$
K^{\prime}=0.52 \cos ^{2} \alpha \cdot \operatorname{ctg} a / \pi .
$$

Researchers N. N. Agranat and M. F. Shirokov [12-14], at the conclusion of the equation for the definition of a cone constant, took into account the influence of the plastic ones; besides the displacement information:

$$
\frac{1}{K^{\prime}}=\pi \operatorname{tg}^{2} \alpha\left\{\begin{array}{l}
2 \alpha-2(\sin \alpha+1)^{2} \cdot \ln \left(\frac{\sin \alpha}{\sin \alpha+1}\right)+ \\
+\left[1-\operatorname{ctg}\left(\frac{\pi}{4}+\frac{\alpha}{2}\right)\right](2 \sin \alpha+1)^{2} \cdot \\
\cdot \ln \left[\frac{2 \sin \alpha}{2(\sin \alpha+1)}\right]+ \\
{\left[\operatorname{ctg}\left(\frac{\pi}{4}+\frac{\alpha}{2}\right)-\operatorname{ctg}\left(\frac{\pi}{4}+\alpha\right)\right] \cdot} \\
\cdot \operatorname{ctg} 2\left(\frac{\pi}{4}-\alpha\right) \cdot \ln \left[\frac{2}{\operatorname{ctg} \alpha+1}\right]+ \\
\operatorname{ctg}\left(\frac{\pi}{4}+\frac{\alpha}{2}\right) \cdot \\
\cdot\left[\operatorname{ctg}\left(\frac{\pi}{4}-\alpha\right)-(2 \sin \alpha+1)\right]
\end{array}\right\}
$$

The significance of the constants calculated with the formula 3 for the indentors with the corner at the top not less $60^{\circ}$, which applied to various viscous-plastic food systems, gave the least error in the values PNS irrespective of used devices. For cones with a smaller corner, errors of measurements were considerable. Therefore V. A. Aret, using a parametrical method, of 3 correction factor $\left(K_{p}\right)$, counted on the following dependence has suggested to enter recognition theories into the equation:

$$
K_{p}=\operatorname{tg} \alpha \frac{\sqrt{9 \operatorname{tg}^{2} \alpha+4}}{3 \operatorname{tg}^{2} \alpha+1} .
$$

Then the specified constant $\left(K_{s}\right)$ will be equal $K_{s}=K^{\prime} \cdot K_{\mathrm{p}}$.

The cone constant calculated under the formulas 3 and 4 taking into account the received A. N. Abramov's correction factor, which allows to lead the values PNS to standard indicators:

$$
K_{p}^{\prime}=1.32 K_{p}=1.32 \operatorname{tg} \alpha \frac{\sqrt{9 \operatorname{tg}^{2} \alpha+4}}{3 \operatorname{tg}^{2} \alpha+1} .
$$

Then the standard constant $\left(K_{s}\right)$ will be equal $K_{s}=K^{\prime} \cdot K_{p}^{\prime}$.

With the similar purpose has been received by V. D. Kosoy and V. S. Katjuhinym, experimentally on the toxitropical coagulative and viscous-plastic structure the amendment to the equation 3 , with the use of indentors with a corner from $20^{\circ}$ to $90^{\circ}$ :

$$
K_{p K^{\prime}}=0.83(1.7-\sin 2 \alpha .
$$

Then the standard constant $\left(K_{s}\right)$ will be equal $K_{s}=K^{\prime} \cdot K_{p K}$.

The simplified equation for the calculation of a cone constant has been received by V. D Kosoy and V. A. Karpychev:

$$
K_{p}=0.687 \operatorname{ctg}^{2} \alpha .
$$

If all calculative sizes equated to the values received by means of a cone with a corner $60^{\circ}$, by V. D Kosoy, and others the simplified empirical amendment $\left(K_{p e}\right)$ would be offered as the equation (6) in the form of rectilinear dependence:

$$
K_{p e}=0.4+0.01 \alpha \text {. }
$$

According to the considered equations the constants werec calculated including account correction factors for the most widespread cones in limits have been calculated, from $10^{\circ}$ to $90^{\circ}$ which values are showed in the Table $1[10], K^{\prime}=K / 9.8$.

According to the presented constants (Table 1) values of limiting pressure of shift on analyzed points for muscles, with a longitudinal and crosssection arrangement have been calculated. Calculations are shown in Tables 2-5.

Comparing the values of DLPS received with the use of various cones: $30^{\circ}, 20^{\circ}, 10^{\circ}$ and calculated with the help of P. A. Rebinder's (formula 1), taking into account the factor, which Agranat N.N. and others, and V. A. Aret's correction (formula 4) has been revealed the best convergence in comparison with the use of the constants received with the help of other researchers....provide references. The use of the given constants at the calculation of DLPS for longitudinal the located muscles is not exceeded $1 \%$ at the estimation of rheological characteristics of pair meat and $1.5 \%$ at a meat estimation in a condition posthumous rigor (tables 2, 4). For cross-section located muscles average value of an error in calculations of fresh meat within $5 \%$, for the stiffened meat slightly exceeds 
$4 \%$ (Tables 3, 5). Distinctions in errors for longitudinal and cross-section located muscles are proved with true the previous conclusions (see [7]) which characterise the display of resilient-elastic deformations at introduction of the indentor in the cross-section.

\section{Table 1}

The values of the constants of the conical indenters $K$ and $K^{\prime}=K / 9.8$ is calculated by the different formulas [10]

\begin{tabular}{|c|c|c|c|c|c|c|c|c|c|c|c|c|c|c|c|}
\hline \multirow[t]{3}{*}{ № } & \multirow{3}{*}{$\begin{array}{l}\text { Equation for constants calculating } \\
K \text { and } K_{\mathrm{\Pi}}\end{array}$} & \multicolumn{14}{|c|}{ Conic indentor with cone at top $(2 \alpha)$} \\
\hline & & \multicolumn{2}{|c|}{$10^{\circ}$} & \multicolumn{2}{|c|}{$20^{\circ}$} & \multicolumn{2}{|c|}{$30^{\circ}$} & \multicolumn{2}{|c|}{$45^{\circ}$} & \multicolumn{2}{|c|}{$60^{\circ}$} & \multicolumn{2}{|c|}{$75^{\circ}$} & \multicolumn{2}{|c|}{$90^{\circ}$} \\
\hline & & $K$ & $K^{\prime}$ & $K$ & $K^{\prime}$ & $K$ & $K^{\prime}$ & $K$ & $K^{\prime}$ & $K$ & $K^{\prime}$ & $K$ & $K^{\prime}$ & $K$ & $K^{\prime}$ \\
\hline 1 & P. A. Rebinder's (1) & 35.6 & 3.63 & 17.15 & 1.75 & 10.88 & 1.11 & 6.45 & 0.66 & 4.05 & 0.41 & 2.57 & 0.26 & 1.56 & 0.16 \\
\hline 2 & Including modifications by Abramova (2) & 18.5 & 1.89 & 8.92 & 0.91 & 5.66 & 0.58 & 3.35 & 0.34 & 2.11 & 0.22 & 1.34 & 0.14 & 0.81 & 0.08 \\
\hline 3 & N. N. Agranat and others. (3) & 29.0 & 2.96 & 17.9 & 1.83 & 9.4 & 0.96 & 4.08 & 0.42 & 2.13 & 0.22 & 1.1 & 0.11 & 0.71 & 0.07 \\
\hline 4 & Including modifications V. A. Areta (4) & 7.58 & 0.77 & 5.98 & 0.61 & 4.47 & 0.46 & 2.63 & 0.27 & 1.61 & 0.16 & 1.0 & 0.10 & 0.64 & 0.07 \\
\hline 5 & Including (5) & 10.0 & 1.02 & 7.89 & 0.81 & 5.9 & 0.60 & 3.47 & 0.35 & 2.13 & 0.22 & 1.32 & 0.14 & 0.85 & 0.09 \\
\hline 6 & Including (6) & 15.78 & 1.61 & 11 & 1.12 & 6.5 & 0.66 & 3.41 & 0.35 & 2.12 & 0.22 & 1.24 & 0.13 & 0.8 & 0.08 \\
\hline 7 & V. D. Kosoy, V. A. Karpichev et al. (7) & - & - & 22.1 & 2.26 & 9.57 & 0.98 & 4.01 & 0.41 & 2.06 & 0.21 & 1.17 & 0.12 & 0.69 & 0.07 \\
\hline 8 & Including $K_{\ni}$ & - & - & 13.3 & 1.36 & 6.7 & 0.68 & 3.41 & 0.35 & 2.06 & 0.21 & 1.35 & 0.14 & 0.9 & 0.09 \\
\hline 9 & $K_{3}(6)$ & 1.53 & 0.16 & 1.36 & 0.14 & 1.20 & 0.12 & 0.99 & 0.10 & 0.83 & 0.09 & 0.73 & 0.08 & 0.70 & 0.07 \\
\hline 10 & $K_{p}^{\prime}=\operatorname{ctg}^{2} \alpha / \pi$ & 41.7 & 4.26 & 102 & 1.04 & 4.44 & 0.45 & 1.86 & 0.19 & 0.96 & 0.10 & 0.54 & 0.06 & 0.32 & 0.03 \\
\hline 11 & $K_{p}^{\prime}=\operatorname{ctg}^{2} \alpha g / \pi$ & 408 & 41.63 & 100 & 10.2 & 43.5 & 4.44 & 18.0 & 1.84 & 9.4 & 0.96 & 5.3 & 0.54 & 3.1 & 0.32 \\
\hline
\end{tabular}

\section{Table 2}

Calculation of LPS with the correctional factors for conic indentors influencing meat at a longitudinal arrangement of muscles in 1 hour after slaughter

\begin{tabular}{|c|c|c|c|c|c|c|c|c|c|c|c|}
\hline № & Equation for constants calculating $K$ and $K_{\mathrm{\Pi}}$ & $K_{10}^{\prime}$ & $\begin{array}{c}\Theta_{\mathrm{o} 10} \\
\mathrm{~kg} / \mathrm{cm}^{2}\end{array}$ & $K_{20}^{\prime \prime}$ & $\begin{array}{c}\Theta_{\mathrm{o} 20}, \\
\mathrm{~kg} / \mathrm{cm}^{2}\end{array}$ & $K^{\prime}{ }_{30}$ & $\begin{array}{c}\Theta_{030}, \\
\mathrm{~kg} / \mathrm{cm}^{2}\end{array}$ & $\underset{\mathrm{kg} / \mathrm{sm}^{2}}{\Theta_{\text {mid }}}$ & $\begin{array}{c}\Delta_{10} \\
\%\end{array}$ & $\begin{array}{c}\Delta_{20}, \\
\%\end{array}$ & $\begin{array}{c}\Delta_{30} \\
\%\end{array}$ \\
\hline 1 & P. A. Rebinder's (1) & 3.63 & 0.2960 & 1.75 & 0.1778 & 1.11 & 0.1475 & 0.2038 & -40.36 & 12.74 & 27.62 \\
\hline 2 & Including modifications by Abramova (2) & 1.89 & 0.1486 & 0.91 & 0.0925 & 0.58 & 0.0767 & 0.1059 & -40.29 & 12.71 & 27.58 \\
\hline 3 & N. N. Agranat and others. (3) & 2.96 & 0.2330 & 1.83 & 0.1856 & 0.96 & 0.1274 & 0.1820 & -28.02 & -1.97 & 29.98 \\
\hline 4 & Including modifications V. A. Areta (4) & 0.77 & 0.0609 & 0.61 & 0.0620 & 0.46 & 0.0606 & 0.0612 & 0.43 & -1.36 & 0.93 \\
\hline 5 & Including (5) & 1.02 & 0.0803 & 0.81 & 0.0818 & 0.60 & 0.0800 & 0.0807 & 0.45 & -1.36 & 0.90 \\
\hline 6 & Including (6) & 1.61 & 0.1268 & 1.12 & 0.1140 & 0.66 & 0.0881 & 0.1096 & -15.62 & -4.01 & 19.64 \\
\hline 7 & V. D. Kosoy, V. A. Karpichev and others. (7) & - & - & 2.26 & 0.2291 & 0.98 & 0.1297 & 0.1196 & 100.00 & -91.55 & -8.45 \\
\hline 8 & Including $K_{\ni}$ & - & - & 1.36 & 0.1379 & 0.68 & 0.0908 & 0.0762 & 100.00 & -80.87 & -19.13 \\
\hline 9 & $K_{3}(6)$ & 0.16 & 0.0123 & 0.14 & 0.0141 & 0.12 & 0.0163 & 0.0142 & 13.56 & 0.84 & -14.40 \\
\hline 10 & $K_{p}^{\prime}=\operatorname{ctg}^{2} \alpha / \pi$ & 4.26 & 0.3350 & 1.04 & 0.1058 & 0.45 & 0.0602 & 0.1670 & -100.63 & 36.67 & 63.96 \\
\hline 11 & $K_{p}^{\prime}=\operatorname{ctg}^{2} \alpha g / \pi$ & 41.63 & 3.2780 & 10.2 & 1.0368 & 4.44 & 0.5897 & 1.6348 & -100.51 & 36.58 & 63.93 \\
\hline
\end{tabular}


Table 3

Calculation of LPS with the correctional factors for conic indentors influencing to meat at a cross-section arrangement of muscles in 1 hour after slaughter

\begin{tabular}{|c|c|c|c|c|c|c|c|c|c|c|c|}
\hline № & Equation for constants calculating $K$ and $K_{\Pi}$ & $K_{10}^{\prime}$ & $\begin{array}{c}\Theta_{\mathrm{o} 10} \\
\mathrm{~kg} / \mathrm{cm}^{2}\end{array}$ & $K_{20}^{\prime}$ & $\begin{array}{c}\Theta_{\mathrm{o} 20}, \\
\mathrm{~kg} / \mathrm{cm}^{2}\end{array}$ & $K_{30}^{\prime \prime}$ & $\begin{array}{c}\Theta_{030}, \\
\mathrm{~kg} / \mathrm{cm}^{2}\end{array}$ & $\begin{array}{c}\Theta_{\text {mid, }} \\
\mathrm{kg} / \mathrm{cm}^{2}\end{array}$ & $\begin{array}{c}\Delta_{10}, \\
\%\end{array}$ & $\begin{array}{c}\Delta_{20}, \\
\%\end{array}$ & $\begin{array}{c}\Delta_{30}, \\
\%\end{array}$ \\
\hline 1 & binder's (1) & 3.63 & 0.1494 & 1.75 & 0.0800 & 1.11 & 0.0745 & 0.1013 & -64.58 & 21.01 & 26.48 \\
\hline 2 & Including modifications by Abramova (2) & 1.89 & 0.0776 & 0.91 & 0.0416 & 0.58 & 0.0387 & 0.0527 & -64.45 & 20.98 & 26.44 \\
\hline 3 & N. N. Agranat and others. (3) & 2.96 & 0.1217 & 1.83 & 0.0835 & 0.96 & 0.0643 & 0.0899 & -49.49 & 7.05 & 28.39 \\
\hline 4 & Including modifications V. A. Areta (4) & 0.77 & 0.0318 & 0.61 & 0.0279 & 0.46 & 0.0306 & 0.0301 & -5.58 & 7.31 & -1.644 \\
\hline 5 & Including (5) & 1.02 & 0.0420 & 0.81 & 0.0368 & 0.60 & 0.0404 & 0.0397 & -5.55 & 7.32 & -1.674 \\
\hline 6 & Including (6) & 1.61 & 0.0662 & 1.12 & 0.0513 & 0.66 & 0.0445 & 0.0540 & -27.44 & 4.98 & 17.62 \\
\hline 7 & V. D. Kosoy, V. A. Karpichev and others. (7) & - & - & 2.26 & 0.1031 & 0.98 & 0.0655 & 0.0562 & 85.80 & -83.45 & -16.55 \\
\hline 8 & Including $\mathrm{K}_{\ni}$ & - & - & 1.36 & 0.0621 & 0.68 & 0.0459 & 0.0360 & 78.44 & -72.51 & -27.49 \\
\hline 9 & $K_{3}(6)$ & 0.16 & 0.0064 & 0.14 & 0.0063 & 0.12 & 0.0082 & 0.0070 & 6.97 & 9.26 & -17.46 \\
\hline 10 & $K_{p}^{\prime}=\mathrm{c}$ & 4.26 & 0.1750 & 1.04 & 0.0476 & 0.45 & 0.0304 & 0.0843 & -298.32 & 43.56 & 63.96 \\
\hline 11 & $K_{p}^{\prime}=\operatorname{ctg}^{2} \alpha g / \pi$ & 41.63 & 1.7123 & 10.2 & 0.4666 & 4.44 & 0.2978 & 0.8256 & -297.77 & 43.48 & 63.93 \\
\hline
\end{tabular}

Table 4

Calculation LPS with correction factors for conic indentors influencing meat at a longitudinal arrangement of muscles in 44 hours after slaughter

\begin{tabular}{|c|c|c|c|c|c|c|c|c|c|c|}
\hline № Equation for constants calculating $K$ and $K_{\mathrm{n}}$ & $K_{10}^{\prime}$ & $\begin{array}{c}\Theta_{\mathrm{o} 10} \\
\mathrm{~kg} / \mathrm{cm}^{2}\end{array}$ & $K_{20}^{\prime}$ & $\begin{array}{c}\Theta_{\mathrm{o} 20}, \\
\mathrm{~kg} / \mathrm{cm}^{2}\end{array}$ & $K_{30}^{\prime}$ & $\begin{array}{c}\Theta_{030}, \\
\mathrm{~kg} / \mathrm{cm}^{2}\end{array}$ & $\begin{array}{c}\Theta_{\text {mid }}, \\
\mathrm{kg} / \mathrm{cm}^{2}\end{array}$ & $\begin{array}{c}\Delta_{10}, \\
\%\end{array}$ & $\begin{array}{c}\Delta_{20}, \\
\mid \%\end{array}$ & $\begin{array}{c}\Delta_{30}, \\
\%\end{array}$ \\
\hline 1 P. A. Rebinder's (1) & 3.63 & 0.4060 & 1.75 & 0.2467 & 1.11 & 0.2159 & 0.2896 & -40.23 & 14.80 & 25.43 \\
\hline 2 Including modifications by $\mathrm{Abr}$ & 1.89 & 0.2110 & 0.91 & 0.1283 & 0.58 & 0.1123 & 0.1505 & -40.16 & 14.77 & 25.38 \\
\hline 3 N. N. Agranat and others. (3) & 2.96 & 0.3308 & 1.83 & 0.2575 & 0.96 & 0.1866 & 0.2583 & -28.07 & 0.31 & 27.76 \\
\hline 4 Including moc & 0.77 & 0.0865 & 0.61 & 0.0860 & 0.46 & 0.0887 & 0.0871 & 0.70 & 1.20 & -1.90 \\
\hline 5 Including (5) & 1.02 & 0.1141 & 0.81 & 0.1135 & 0.60 & 0.1171 & 0.1149 & 0.72 & 1.21 & -1.93 \\
\hline 6 Including (6) & 1.61 & 0.1800 & 1.12 & 0.1582 & 0.66 & 0.1290 & 0.1557 & -15.57 & -1.60 & 17.17 \\
\hline 7 V. D. Kosoy, V. A. Karpichev et al. (7) & - & - & 2.26 & 0.3179 & 0.98 & 0.1899 & 0.1693 & 100.00 & -87.80 & -12.20 \\
\hline 8 Including $K_{\ni}$ & - & - & 1.36 & 0.1913 & 0.68 & 0.1330 & 0.1081 & 100.00 & -76.98 & -23.02 \\
\hline $9 K_{3}(6)$ & 0.16 & 0.0175 & 0.14 & 0.0196 & 0.12 & 0.0238 & 0.0203 & 13.94 & 3.52 & -17.46 \\
\hline $10 K_{p}^{\prime}=\mathrm{c}$ & 4.26 & 0.4756 & 1.04 & 0.1467 & 0.45 & 0.0881 & 0.2368 & -100.84 & 38.05 & 62.79 \\
\hline $11 K_{p}^{\prime}=\operatorname{ctg}^{2} \alpha g / \pi$ & 41.63 & 4.6535 & 10.2 & 1.4384 & 4.44 & 0.8633 & 2.3184 & -100.72 & 37.96 & 62.76 \\
\hline
\end{tabular}

Table 5

Calculation LPS with correctional factors for conic indentors influencing meat at a cross-section arrangement of muscles in 44 hours after slaughter

\begin{tabular}{|c|c|c|c|c|c|c|c|c|c|c|c|}
\hline № & Equation for constants calculating $K$ and $K_{p}$ & $K_{10}^{\prime}$ & $\begin{array}{c}\Theta_{010}, \\
\mathrm{~kg} / \mathrm{cm}^{2}\end{array}$ & $K_{20}^{\prime}$ & $\begin{array}{c}\Theta_{\mathrm{o} 20}, \\
\mathrm{~kg} / \mathrm{cm}^{2}\end{array}$ & $K_{30}^{\prime}$ & $\begin{array}{c}\Theta_{030}, \\
\mathrm{~kg} / \mathrm{cm}^{2}\end{array}$ & $\begin{array}{c}\Theta_{\text {mid }}{ }_{2} \\
\mathrm{~kg} / \mathrm{sm}^{2}\end{array}$ & $\begin{array}{c}\Delta_{10}, \\
\%\end{array}$ & $\begin{array}{c}\begin{array}{c}\Delta_{20}, \\
\%\end{array} \\
\%\end{array}$ & $\begin{array}{c}\Delta_{30} \\
\%\end{array}$ \\
\hline 1 & P. A. Rebinder's (1) & 3.63 & 0.2464 & 1.75 & 0.1360 & 1.11 & 0.1173 & 0.1666 & -47.92 & 18.37 & 29.56 \\
\hline 2 & Including modifications by Abramova (2) & 1.89 & 0.1280 & 0.91 & 0.0707 & 0.58 & 0.0610 & 0.0866 & -47.85 & 18.34 & 29.52 \\
\hline 3 & N. N. Agranat and others. (3) & 2.96 & 0.2007 & 1.83 & 0.1419 & 0.96 & 0.1014 & 0.1480 & -35.61 & 4.11 & 31.51 \\
\hline 4 & Including modifications V. A. Areta (4) & 0.77 & 0.0525 & 0.61 & 0.0474 & 0.46 & 0.0482 & 0.0494 & -6.28 & 3.95 & 2.34 \\
\hline 5 & Including (5) & 1.02 & 0.0692 & 0.81 & 0.0626 & 0.60 & 0.0636 & 0.0651 & -6.26 & 3.96 & 2.31 \\
\hline 6 & Including (6) & 1.61 & 0.1092 & 1.12 & 0.0872 & 0.66 & 0.0701 & 0.0888 & -22.93 & 1.83 & 21.10 \\
\hline 7 & V. D. Kosoy, V. A. Karpichev and others. (7) & - & - & 2.26 & 0.1752 & 0.98 & 0.1032 & 0.0928 & 100.00 & -88.80 & -11.20 \\
\hline 8 & Including $K_{\ni}$ & - & - & 1.36 & 0.1055 & 0.68 & 0.0723 & 0.0592 & 100.00 & -78.02 & -21.98 \\
\hline 9 & $K_{3}(6)$ & 0.16 & 0.0106 & 0.14 & 0.0108 & 0.12 & 0.0129 & 0.0114 & 7.42 & 5.73 & -13.15 \\
\hline & $K_{p}^{\prime}=\operatorname{ctg}^{2} \alpha / \pi$ & 4.26 & 0.2886 & 1.04 & 0.0809 & 0.45 & 0.0479 & 0.1391 & -107.45 & 41.87 & 65.58 \\
\hline & $K_{p}^{\prime}=\operatorname{ctg}^{2} \alpha g / \pi$ & 41.63 & 2.8240 & 10.2 & 0.7929 & 4.44 & 0.4692 & 1.3620 & -107.34 & 41.79 & 65.55 \\
\hline
\end{tabular}




\section{CONCLUSION}

Thus, the methods of definition DLPS in the example of whole muscle meat and other resilientelastic products, including experimentally received rational values of parametres of its measurement is preliminary developed: conic indentor with the corner 10 and the set effort of resistance of a product equal $0.5 \mathrm{~kg}$ at which achievement there comes to the balance of the system. For an estimation of the quality of corresponding systems it is desirable to measure the size of a penetration which is necessary for calculation of DLPS, at introduction of indentor in it is longitudinal-located muscles.

The technique of definition of DLPS in the example of solid muscle meat, including experimentally received rational values of parametres of its measurement and calculation with the use of constants of cones calculated by N. N. Agranat with V. A. Aret's amendment is improved. The chosen factors provide the minimum disorder of values DLPS that allows to recommend them for the further calculations.

\section{REFERENCES}

[1] Poldvere A., Lepasalu L., Tanavots A., Olt J., Sannik U., Sats A., Saar R., Martinson R. and Poikalainen V.: An alternative method for meat shear energy estimation during ageing. J. Agronomy Research, 12 (3), 793-800 (2014).

[2] Migdał W., Živković B., Nowocień A., I. Przeor I., Palka K., Natonek-Wiśniewska M., Wojtysiak D., Walczycka M., I. Duda I.: Chemical composition and texture parameters of loin from polish landrace fatteners slaughtered in different age. J. Biotechnology in Animal Husbandry, 23 (5-6), 277-282 (2007).
[3] Aret A. V., Zabrovskij G. P., Nikolaev B. L., Nikolaev L. K.: Engineering Rheology of Fat-containing Foods. St. Petersburg State University of Refrigeration and Food Technology, 2002, 130-139.

[4] Kosoy V. D., Dorohov V. P.: Improving the production of sausages (theoretical foundations, processes, equipment, technology, formulations and quality control), M., DeLi print, 2006, 72-99.

[5] Aitbek Kakimov, Zhanibek Yessimbekov, Aigerim Bepeyeva, Bolat Kabulov and Zhainagul Kakimova: Consistency cone penetrometry for food products. Pakistan Journal of Nutrition, 14 (11) 837-840 (2015).

[6] Kosoy V. D., Malyshev A. D., Yudina S. B.: Engineering rheology in the production of sausages, M., KolosS, $2005,262$.

[7] Savinok O. N.: Rheometrik investigations of beef muscle tissue in different periods of autolysis. Maced. J. Anim. Sci., Vol. 5, No. 2, 101-105 (2015).

[8] Savinok O. N., Azarova N. G., Kosoy V. D., Rizhov S. A.: Kinetics of beef maturation in one-step cooling, $J$. Meat Industry, 5, 58-62 (2011).

[9] Savinok O. N.: The kinetics of the functional meat parameters depending on the duration of its exposure after slaughter. J. Storage and Processing of Agricultural. 4. 35-41 (2014).

[10] Kosoy V. D., Dunchenko N. I., Merkulov M. U.: Rheology of Dairy Products, M., Deli print, 2010, 212-217.

[11] Rebinder P. A., Semenenko N. A.: The method of dipping the cone to characterize structural and mechanical properties of the plastic-viscous bodies, AS USSR T 64, № 6, $115-126$ (1949).

[12] Guskov K. P., Machihin A. Y., Machihin S. A., Lunin L. N.: Rheology of Food Weight, M., Food Industry, 27-54 (1970).

[13] Gorbatov A. V.: Rheology meat and dairy products. M., Food industrial laziness, 133-137 (1979).

[14] Kosoy V. D.: Improvement of the Production Process of Cooked Sausages, M., Light and food industries, 145-157 (1983). 